\title{
LOS INTELECTUALES Y \\ EL DEBATE POLÍTICO EN LA ARGENTINA ${ }^{1}$
}

CARLOS ALTAMIRANO

CONICET

La intervención política de los intelectuales ha sido un hecho recurrente en la Argentina. Los partidos que contaban con favor popular, sin embargo, como el radicalismo en la primera mitad del siglo XX, y el peronismo desde 1946, nunca fueron demasiado hospitalarios con los «hombres de ideas». Durante décadas, los intelectuales que sentían vocación por el compromiso cívico apoyaron por lo general a formaciones políticas minoritarias, el socialismo o el comunismo, en la franja izquierda del campo político; el nacionalismo, en la franja derecha. Las tentativas de encontrarse con el pueblo -como la que emprendieron en los primeros años setenta grupos de universitarios marxistas y católicos que se proclamaron peronistas con el propósito de fusionarse con las masas y hacer la revolución- no terminaron bien.

El retorno de la democracia en 1983 dejó percibir que algo había cambiado, del lado de los políticos y del lado de los intelectuales. El gobierno de Raúl Alfonsín, que pertenecía al ala progresista del partido Radical, incorporó a numerosos intelectuales en puestos de gestión o como asesores de su gobierno. En general ellos no pertenecían al radicalismo y la mayoría procedía de la franja izquierda de la intelligentsia. La construcción de una democracia social y las raíces del autoritarismo en la cultura argentina se volvieron temas de preocupación en los ambientes ilustrados progresistas, sus revistas y sus libros. La izquierda intelectual del peronismo, que provenía de la experiencia de los años setenta, no se mantuvo inactiva: se agrupó ligándose a los sectores renovadores del partido peronista para rivalizar con el radicalismo en la lucha por una democracia avanzada. La revista Unidos fue su órgano de expresión.

Ese escenario se hundió en 1987, cuando los amotinamientos militares hicieron retroceder al gobierno de Alfonsín. El daño que sufrió la imagen del presidente se reflejó en la aplastante derrota electo-

\footnotetext{
${ }^{1}$ Este texto es una versión revisada de la intervención del autor en oportunidad de la presentación del número homenaje a Darío Macor de Estudios Sociales, en el marco de las Segundas Jornadas de Ciencia Política del Litoral, Santa Fe, Universidad Nacional del Litoral, 30 de mayo de 2014.
} 
ral que su partido sufrió ese mismo año. La hiperinflación de 1989 completó la demolición del proyecto alfonsinista. El peronismo volvió al gobierno con Carlos Menem, que durante 10 años hizo de su partido el instrumento del «partido del mercado». Aliado con la derecha liberal, Menem no reclutó casi intelectuales, sino técnicos y expertos, elegidos para ejecutar las reformas que esa derecha había solicitado durante mucho tiempo. El colapso que conoció el país en el 2001 y arrastró al gobierno de la Alianza, fue la clausura de la temporada neoliberal.

El proceso actualmente en curso nació de ese gran sacudimiento. El término corriente para designar el ciclo político que comenzó en 2003 con el gobierno de Néstor Kirchner es, precisamente, el de "kirchnerismo», que evoca tanto una coalición gobernante como un estilo de gestión, un movimiento político y la jefatura de ese movimiento. Néstor Kirchner arribó al gobierno cuando el país iniciaba una nueva e inesperada etapa de crecimiento, cuya base era la producción agraria y el amplio mercado que China y otros países abrieron para ella. Aún permanecían, sin embargo, los enormes estragos sociales que habían producido las políticas neoliberales y la quiebra de 2001. Ambos, Néstor y Cristina Kirchner, que hasta la muerte del ex presidente constituyeron el núcleo de la coalición gobernante, provenían de las filas del peronismo de izquier- da. Aunque no habían hecho oposición al gobierno de Carlos Menem, desde su llegada al gobierno los Kirchner hicieron del pasado juvenil un signo de identidad del kirchnerismo. La renovación de la Corte Suprema de justicia, la política en el campo de los derechos humanos y el impulso que dio a los juicios a militares le darían al nuevo gobierno amplio apoyo en la opinión progresista. Reforzaron ese respaldo los enfrentamientos con el establishment empresario y las disputas con la jerarquía eclesiástica. El estímulo al mercado interno redujo fuertemente el desempleo y los salarios mejoraron en el marco de una administración que le devolvió al Estado un papel activo en la economía, junto con una política social reparadora de los daños producidos en los años noventa.

Poco a poco el kirchnerismo dividirá a ese mismo universo progresista que cautivó al principio. Por cierto, atrajo la colaboración de muchos intelectuales de izquierda, algunos de los cuales se incorporarían al elenco de funcionarios -Torcuato Di Tella, José Nun, Horacio González-. Otros asumirían la defensa pública de la empresa kirchnerista en libros y columnas periodísticas, sin ocupar cargos en el Estado, como José Pablo Feinmann. En el 2008, el conflicto entre el gobierno y el conjunto de las organizaciones rurales precipitó la cristalización de un vasto cuerpo de intelectuales orgánicos del kirchnerismo. Se movilizaron 
y se constituyeron en un movimiento, "Carta Abierta», que dará respaldo al gobierno de Cristina F. de Kirchner, titular del ejecutivo para entonces. En el primero de sus documentos, o "cartas», denunciarán que el gobierno democrático se veía jaqueado por una confluencia de intereses que reunía a las clases dominantes con el poder mediático.

La controversia sobre el kirchnerismo en el medio intelectual, que ya se había entablado, se volvió más enconada. Surgieron otros agrupamientos intelectuales, opuestos a la política en curso, como el Club Político y Plataforma 2012. Los críticos, como la ensayista Beatriz Sarlo, pondrán el acento en el carácter cesarista y en el au- toritarismo del gobierno, en su aversión al pluralismo, la manipulación clientelista de sus políticas sociales, en la corrupción de los funcionarios y la falsificación de la información estadística, en su desprecio por la deliberación democrática, en el carácter arcaico de su nacionalismo.

Aunque en la actualidad se asiste al fin del ciclo kirchnerista en el gobierno, puede vaticinarse que el debate intelectual sobre el camino que permita enlazar la democracia política y el combate contra la desigualdad social, la autonomía nacional y la ampliación de las libertades, proseguirá. ¿Es el camino del neo-populismo? ¿Hay que esperar alguna versión de la socialdemocracia? 
